\title{
PENGARUH TINGKAT PEMBERIAN EKSTRAK DAUN BURAHOL (Stelechocarpus burahol) DALAM RANSUM TERHADAP BOBOT ORGAN DALAM AYAM BROILER
}

\section{The Effect a Levels of Burahol (Stelechocarpus Burahol) Leaves Extract in The Diet on Internal Organs Weigh of Broiler Chickens}

\author{
Serli Mistiani ${ }^{1}$, Kurnia A. Kamil ${ }^{2}$, Denny Rusmana ${ }^{2}$ \\ ${ }^{1}$ Program Sarjana Ilmu Peternakan, Fakultas Peternakan, Universitas Padjadjaran \\ Kampus Jatinagor, Jl. Raya Bandung-Sumedang KM.21, Jatinangor-Sumedang, \\ Jawa Barat 45363 \\ ${ }^{2}$ Departemen Nutrisi Ternak dan Teknologi Ternak Pakan, Fakultas Peternakan, Universitas \\ Padjadjaran. Kampus Jatinangor, J1. Raya Bandung-Sumedang KM.21, Jatinangor- \\ Sumedang, Jawa Barat 45363
}

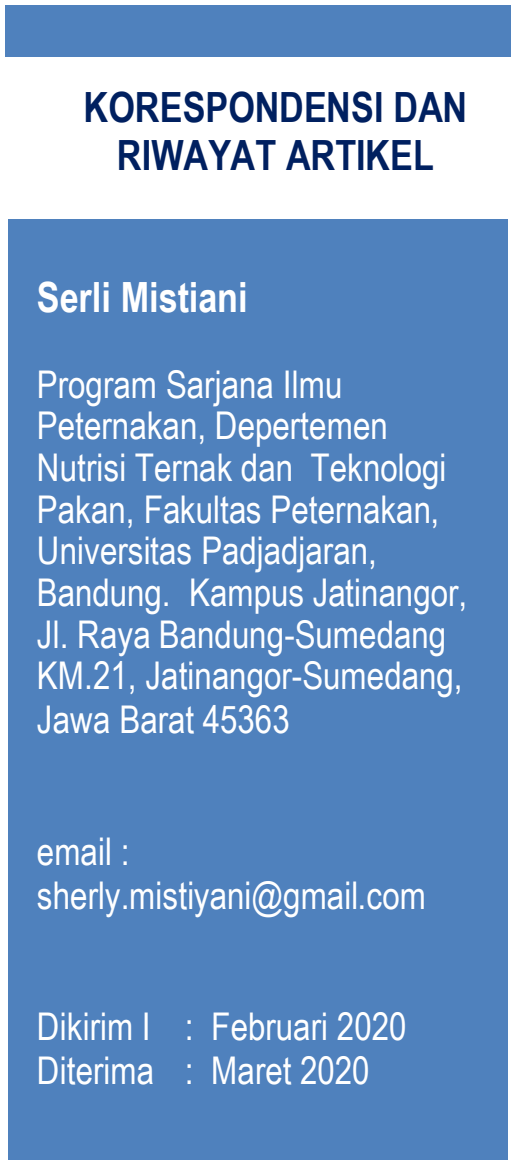

\begin{abstract}
ABSTRAK
Penelitian ini bertujuan untuk mengetahui pengaruh tingkat pemberian ekstrak daun burahol (Stelechocarpus burahol) dalam ransum terhadap bobot organ dalam ayam broiler. Metode yang digunakan dalam penelitian adalah eksperimental dengan rancangan percobaan rancangan acak lengkap (RAL) dengan empat perlakuan dan lima ulangan. Keempat perlakuan tersebut adalah sebagai berikut: Perlakuan P0 berupa pemberian tanpa penambahan ekstrak daun burahol dalam ransum sebagai kontrol, P1= Pakan basal $+0,15 \%$ ekstrak daun burahol, $\mathrm{P} 2=$ Pakan basal + $0,30 \%$ ekstrak daun burahol dan P3= Pakan basal $+0,45 \%$ ekstrak daun burahol. Peubah yang diamati adalah bobot jantung, bobot hati, bobot proventrikulus, bobot ventrikulus dan bobot usus halus ayam broiler. Data hasil penelitian diolah menggunakan analisis ragam. Data hasil penelitian menunjukan bahwa perlakuan tidak memberikan pengaruh nyata $(\mathrm{P}>0.05)$ terhadap bobot jantung, bobot hati, bobot ventrikulus, bobot proventrikulus, dan bobot usus halus ayam broiler.
\end{abstract}

Kata Kunci: burahol, broiler, organ

\section{ABSTRACT}

The aim of this research to determine the effect a levels of burahol (Stelechocarpus burahol) leaves extract on the diet to internal organs broiler chickens. The study used an expemimental 
method with a completely randomized design (CRD) with four treatments and five repetitions. The experimental animals were distributed into four treatments groups as follows: PO (diet without burahol leaves extract) , P1 (diet $+0.15 \%$ burahol leaves extract, $P 2$ diet $+0.30 \%$ burahol leaves extract and P3 (diet $+0.45 \%$ burahol leaves extract). The observed parameters were heart weight, liver weight, proventriculus weight, ventriculus weight and small intestie weight of broiler's chickens. The data were analysed by variance analysis. The results of this research showed that the treatment did not have a significant effect $(P>0.05)$ to the heart weight, liver weight, proventriculus weight, ventriculus weight and small intestie weight of broiler chickens.

Keywords: burahol, broiler chickens, organs

\section{PENDAHULUAN}

Ayam broiler adalah ayam tipe pedaging yang paling umum diternakkan untuk menghasilkan daging dalam jangka waktu yang singkat yaitu dapat dipelihara dalam waktu 21-35 hari (Jumiati, 2017). Berbagai upaya dilakukan peternak untuk meningkatkan produktivitas ayam broiler, seperti perbaikan tata laksana pemeliharaan perkandangan dan pakan termasuk penambahan feed additive seperti antibiotik. Namun, akibat penggunaan antibiotik tak terkontrol dalam campuran pakan dapat menyebabkan residu pada produk ternak yang dihasilkan (Bahri dkk., 2005) dan merugikan kesehatan manusia yang mengkonsumsinya, maka perlu dicari bahan alternatif lain pengganti antibiotik sintetis dengan memanfaatkan tanaman herbal yang mempunyai fungsi seperti antibiotik di antaranya tanaman burahol.

Burahol (Stelechocarpus burahol) merupakan salah satu tanaman buah dari famili Annonacea yang berkhasiat obat. Tanaman burahol sangat potensial untuk dikembangkan sebagai komoditi hasil hutan bukan kayu (HHBK) yang dapat dimanfatkan sebagai obat dan kosmetika (Kusmiyati dkk., 2005). Bagian tanaman burahol yang dapat digunakan sebagai obat diperoleh dari daun, kulit, batang dan buah (Heyne, 1987). Daun burahol mengandung senyawa terpenoid dan flavonoid (Purwatiningsih et al., 2011: Aziz and Ramadhan, 2013).

Flavonoid adalah salah satu zat aktif yang terdapat pada daun burahol. Flavonoid memiliki aktivitas biologis sebagai antibiotik
(Cushnie and Lamb, 2005). Antibiotik alamiah umumnya digunakan sebagai pencegahaan dan pengobatan terhadap infeksi bakteri (Mushawwir dkk., 2019). Pada industri peternakan, antibiotik digunakan sebagai imbuhan pakan (feed additive) untuk memacu pertumbuhan (growth promotor), meningkatkan produksi, dan meningkatkan efiensi penggunaan pakan (Bahri dkk., 2005).

Hasil - hasil penelitian terdahulu menunjukan beberapa zat- zat aktif dari bahan alami berpotensi sebagai zat additive untuk meningkatkan immunitas dan memperbaiki profil darah (Mushawwir et al., 2018). Penambahan ekstrak daun burahol yang mengandung senyawa flavonoid pada ransum diharapkan dapat memperbaiki efisiensi penggunaan ransum sehingga dapat menghasilkan nilai konversi yang rendah dan meningkatkan produktivitas ternak tanpa menimbulkan kelainan pada organ dalam ayam broiler.

Ransum yang diberikan pada ternak dapat mempengaruhi kerja organ dalam dan saluran pencernaan ayam (Regar dkk., 2018). Sistem organ pencernaan berkembang sesuai dengan ransum yang diberikan. Kelainan pada organ dalam biasanya ditandai dengan adanya perubahan organ dalam secara fisik seperti perubahan ukuran serta kadar ammonia feces dan metabolic reseptor olfaktori (Mushawwir et al., 2010; 2011).

Berdasarkan uraian di atas, penulis tertarik melakukan penelitian tentang "Pengaruh Tingkat Pemberian Ekstrak Daun Burahol (Stelechocarpus burahol) Dalam 
Ransum Terhadap Bobot Organ Dalam Ayam Broiler".

\section{METODE PENELITIAN}

Hewan percobaan yang digunakan dalam penelitian adalah 100 ekor day old chick (DOC) broiler strain cobb, dipelihara sampai umur 30 hari. Sistem pemeliharaan pada ternak percobaan dilakukan secara acak yang dibagi ke dalam 20 petak kemudian ditempatakan kedalam 4 perlakuan dan dilakukan pengulangan sebanyak 5 kali, masing-masing ulangan terdiri dari 5 ekor ayam. Setiap ternak percobaan diberi nomor pada bagian sayapnya (wing tag) sesuai dengan perlakuan, guna memudahkan dalam pengamatan dan pengambilan data selama pemeliharaan. Empat perlakuan 5 ulangan, masing-masing $\mathrm{P} 0$ :Ransum yang tidak ditambah ekstrak daun burahol; P1: Ransum yang ditambah 0,15\% ekstrak daun burahol; P2:Ransum yang ditambah $0,30 \%$ ekstrak daun burahol; P3:Ransum yang ditambah 0,45\% ekstrak daun burahol.

\section{Pembuatan Ekstrak Daun Burahol}

Ekstrak daun burahol yang dicampurkan ke dalam ransum dipellet terlebih dahulu kemudian diberikan pada ternak. Sebelum memulai ekstraksi, dilakukan persiapan bahan baku yang mencakup pengeringan daun burahol dan pemotongan daun burahol untuk mempermudah proses ekstraksi. Ekstraksi daun burahol pada penelitian ini dilakukan dengan metode maserasi selama 48 jam, menggunakan pelarut yang sesuia tanpa adanya pemanasan (Voight, 1995). Alkohol merupakan pelarut universal yang baik untuk mengekstraksi semua golongan senyawa metabolit sekunder (Depkes, 2000). Hasil maserasi (maserat) disaring dengan corong saring dan ditampung filtratnya, lalu dipekatkan menggunakan alat rotary evaporator pada suhu $40^{\circ} \mathrm{C}$ hingga didapatkan ekstrak kental daun burahol.

\section{Paramater Penelitian}

Parameter yang diamati dalam penelitian ini adalah bobot dan persentase bobot dari organ jantung, hati, proventrikulus, ventrikulus dan usus halus ayam broiler. Persentase bobot diperoleh dari pembagian antara bobot organ (gram) dengan bobot hidup broiler (gram) dikalikan 100\% (setelah disihkkan lemak yang melekat) (Auza, 2010).

\section{Analisis Statistika}

Data dianalisis dengan Uji Sidik Ragam Ranacangan Acak Lengkap, apabila hasil analisis varian yang diperoleh berbeda nyata, maka untuk menguji perbedaan ratarata perlakuan dilakukan Uji Wilayah Berganda Duncan (Gaspersz, 1991).

\section{HASIL DAN PEMBAHASAN}

Berat dan persentase organ dalam (abdominal) ayam broiler yang diberi perlakuan ekstrak buraho, ditampilkan pada Tabel 1 dan 2. Hasil analisis ragam menunjukkan bahwa tingkat pemberikan ekstrak daun burahol dalam ransum tidak berpengaruh nyata $(\mathrm{P}>0,05)$ terhadap bobot jantung ayam broiler umur 30 hari walaupun bobot jantung tiap perlakuan cenderung lebih besar dari kontrol tetapi masih di dalam batas normal. Pembesaran ukuran jantung biasanya disebabkan oleh adanya penambahan jaringan otot jantung (Aqsa dkk., 2016). Ekstrak daun burahol mengandung senyawa flavonoid meliputi auron, flavanon dan flavanol yang dapat digunakan sebagai antibakteri (Hidayat et al., 2011). Menurut Ouyang et al., (2016) flavonoid dapat meningkatkan ekspresi insulin-like growth factor (IGF1) yang berperan sebagai mediator dalam proliferasi fibroblas dan sintesis kolagen, sehingga memicu pertumbuhan masa otot.

Unggas umumnya memiliki ukuran jantung yang bervariasi, persentase bobot jantung ayam broiler 0,42- $0,70 \%$ bobot hidup (Putnam, 1991). Bobot jantung ayam 
broiler yang dihasilkan pada penelitian ini seberat $6,4-7,8$ gram atau $0,57-0,68 \%$ dapat dikatakan normal. Hal tersebut juga menunjukan bahwa perlakuan dengan penambahan ekstrak daun burahol dalam ransum tidak mengandung senyawa berbahaya yang bersifat racun bagi ayam broiler. Menurut Ververidis et al., (2007) dan Adriani et al. (2018) flavonoid pada daun burahol memiliki efek antioksidan sebagai cardioprotect. dalam ransum tidak mengandung senyawa berbahaya yang bersifat racun bagi ayam broiler.

Daun burahol mengandung senyawa flavonoid sebagai antioksidan penangkap radikal bebas (Sunarni dkk., 2007). Dasagupta et al., (2013) menyatakan flavonoid, tanin, dan vitamin $\mathrm{C}$ adalah senyawa yang berfungsi sebagai hepatoprotektor. Flavonoid memiliki efek hepatoprotektor dengan bertindak sebagai

Tabel 1. Rataan Bobot Organ Dalam Ayam Broiler

\begin{tabular}{ccccc}
\hline \multirow{2}{*}{ Parameter } & \multicolumn{4}{c}{ Perlakuan } \\
\cline { 2 - 5 } & P0 & P1 & P2 & P3 \\
\hline Jantung (g) & 6,4 & 7,6 & 7,4 & 7,8 \\
Hati (g) & 24 & 28,2 & 26 & 26,8 \\
Proventrikulus (g) & 5,4 & 6,4 & 5,8 & 6 \\
Ventrikulus (g) & 19,2 & 24,2 & 20,2 & 20,8 \\
Usus Halus (g) & 26 & 30,4 & 27,6 & 28,6 \\
\hline
\end{tabular}

Keterangan : $\mathrm{P} 0=$ ransum basal (kontrol), $\mathrm{P} 1=$ ransum basal+ 0,15\% Ekstrak Daun Burahol(EDB) $\mathrm{P} 2=$ ransum basal $+0,30 \% \mathrm{EDB}, \mathrm{P} 3=$ ransum basal $+0,45 \% \mathrm{EDB}$.

Aqsa dkk., (2016) menyatakan bahwa jantung sangat rentan terhadap racun dan zat antinutrisi, pembesaran jantung dapat terjadi karena adanya akumulasi racun pada otot jantung. Ketika dalam darah mengandung racun dan antinutrisi maka akan memicu kontraksi yang berlebihan sehingga menimbulkan pembengkakan jantung (Aqsa dkk., 2016). Faktor yang mempengaruhi ukuran jantung yaitu jenis kelamin, umur, bobot badan dan aktivitas ternak tersebut (Aqsa dkk., 2016).

Hasil analisis ragam menunjukkan bahwa pemberian ekstrak daun burahol dalam ransum tidak memberikan pengaruh yang nyata $(\mathrm{P}>0,05)$ pada bobot hati ayam broiler walaupun bobot hati tiap perlakuan cenderung lebih besar dari kontrol tetapi masih di dalam batas normal. Putnam (1991), menyatakan bobot hati normal berkisar 1,70 $\%-2,80 \%$ dari bobot hidup dan berdasarkan data hasil penelitian dengan pemberian ekstrak daun burahol menghasilkan rataan bobot hati 24 - 26,8 gram atau 2,18 - 2,36\% dari bobot hidup dapat dikatakan normal. Hal tersebut juga menunjukan bahwa perlakuan dengan penambahan ekstrak daun burahol scavenger radikal bebas yang berikatan langsung dengan ROS/RNS dan meningkatkan aktivitas antioksidan endogen (glutathione) dalam menekan produksi radikal bebas di dalam sel hati (Ramadhina dkk., 2019), serta sebagai inhibitor aktivitas CYP3A (Wu et al., 2006; Hidaka et al., 2006).

Hati berfungsi menyimpan gula dalam bentuk glikogen dan menghasilkan cairan empedu yang berfungsi mengemulsi lemak pada pakan. Senyawa bioaktif pada pakan dapat meningkatkan fungsi hati untuk mensekresikan cairan empedu sehingga meningkatkan masa organ hati (Swarayana dkk., 2012; Cahyono dkk., 2012; Mushawwir dan Latipudin, 2012). Diduga senyawa bioaktif pada ekstrak daun burahol yaitu flavonoid dapat meningkatkan fungsi hati pada ayam broiler sehingga masa organ hati meningkat meskipun tidak berbeda secara statistik.

Ukim et al., (2012) menyatakan persentase bobot proventrikulus broiler normal berkisar antara $0,40-0,54 \%$ dari bobot hidup. Bobot yang dihasilkan pada penelitian sebesar 5,4-6 gram atau 4,8- 
5,4\% dari bobot hidup dapat dikatakan normal. Hasil analisis ragam menunjukkan bahwa pemberian tingkat ekstrak daun burahol dalam ransum tidak berpengaruh nyata $(\mathrm{P}>0,05)$ terhadap bobot proventrikulus ayam broiler umur 30 hari. Hal ini terjadi karena ekstrak daun burahol tidak memberikan pengaruh terhadap bobot proventrikulus, namun besar kecilnya proventrikulus dipengaruhi oleh pakan ternak (Amrullah, 2004) ventrikulus $(\mathrm{P}>0,05)$. Hal ini terjadi karena besar kecilnya bobot ventrikulus lebih dipengaruhi oleh aktivitas kerja ventrikulus dan jenis pakan yang diberikan (Rohmah dkk., 2016).

Penggunaan jenis pakan yang sama dengan tekstur dan bentuk pakan yang sama pada penelitian ini mengakibatkan tidak adanya aktivitas yang berbeda pada ventrikulus masing-masing perlakuan sehingga tidak ada perbedaan ukuran dan

Tabel 2. Rataan Persentase Bobot Organ Dalam Ayam Broiler

\begin{tabular}{ccccc}
\hline \multirow{2}{*}{ Parameter } & \multicolumn{5}{c}{ Perlakuan } \\
\cline { 2 - 5 } & P0 & P1 & P2 & P3 \\
\hline Jantung & 6,4 & 7,6 & 7,4 & 7,8 \\
Hati & 24 & 28,2 & 26 & 26,8 \\
Proventrikulus & 5,4 & 6,4 & 5,8 & 6 \\
Ventrikulus & 19,2 & 24,2 & 20,2 & 20,8 \\
Usus Halus & 26 & 30,4 & 27,6 & 28,6 \\
\hline
\end{tabular}

Keterangan : $\mathrm{P} 0=$ ransum basal (kontrol), $\mathrm{P} 1=$ ransum basal+ 0,15\% Ekstrak Daun Burahol(EDB), $\mathrm{P} 2=$ ransum basal $+0,30 \% \mathrm{EDB}, \mathrm{P} 2=$ ransum basal $+0,45 \% \mathrm{EDB}$.

Ukuran panjang, tebal dan berat saluran pencernaan unggas bukan besaran yang statis (Amrullah, 2004). Perubahan dapat terjadi selama proses perkembangan karena dipengaruhi oleh jenis ransum yang diberikan. Ransum yang banyak mengandung serat akan menimbulkan perubahan ukuran saluran pencernaan sehingga menjadi lebih berat, lebih panjang dan lebih tebal.

Semakin banyaknya fitat dalam ransum basal yang diberikan ke ayam pedaging akan mempengaruhi ukuran proventrikulus, karena proventrikulus bekerja mensekresikan enzim pepsin dan menghasilkan $\mathrm{HCl}$. Leeson and Summer (2005) melaporkan semakin tingginya serat kasar dan fitat pada pakan yang akan diberikan kepada ayam pedaging maka akan mempengaruhi pembesaran dan penipisan organ proventrikulus.

Putnam (1991) menyatakan bahwa persentase bobot ventrikulus berkisar antara 1,62 - 2,3\% dari bobot hidup. Bobot yang dihasilkan pada penelitian sebesar 20,6-24,2 gram atau $1,76-1,84 \%$ dari bobot hidup dapat dikatakan normal. Hasil analisis ragam menunjukan bahwa pemberian ekstrak daun burahol tidak mempengaruhi bobot bobot ventrikulus. Selain itu, kandungan serat kasar ransum yang mencapai 3,83\% tidak membuat kontraksi otot ventrikulus bekerja keras untuk memecah partikel pakan yang berserat, sehingga bobot yang dihasilkan tidak memperlihatkan perbedaan yang nyata. Anggorodi (1994) menyatakan peningkatan serat kasar dalam ransum mengakibatkan ventrikulus akan bekerja lebih intensif untuk mencerna serat kasar, sehingga dapat mengakibatkan peningkatan bobot ventrikulus.

Berdasarkan Tabel 4 dan Tabel 5, rataan bobot usus halus ayam broiler yang dihasilkan adalah 25,8 - 30,2 gram dengan persentase 2,38- 2,51\% dari bobot hidup. Hasil penelitian menunjukan bahwa persentase bobot usus halus hasil penelitian masih dalam batas normal dan sesuai dengan penelitian lainnya yaitu $2,00-2,31 \%$ bobot hidup (Mutia dkk., 2017) dan 2,98\% dari bobot hidup (Awad et al., 2009).

Hasil analisis ragam menunjukan perlakuan pemberian ekstrak daun burahol dalam ransum tidak berbeda nyata $(\mathrm{P}>0,05)$ terhadap bobot usus halus ayam broiler. Hal tersebut diduga karena kandungan serat kasar 
yang dikonsumsi oleh ayam broiler sama antar perlakuan sehingga rataan persentase bobot usus halus yang dihasilkan tidak berbeda secara statistik.

Bobot usus halus dipengaruhi oleh kandungan nutrien dalam ransum, bahan pakan berserat kasar tinggi dalam ransum secara nyata meningkatkan bobot usus halus (Iyayi et al., 2005). Semakin tinggi serat kasar dalam ransum, maka laju pencernaan dan laju penyerapan nutrien akan semakin lambat, untuk memaksimalkan penyerapan zat makanan tersebut, maka daerah penyerapan akan diperluas atau diperpanjang (Syamsuhaidi, 1997).

Adapun kecenderungan bobot usus halus yang lebih besar dari kontrol, masih dalam bobot normal dan tidak berbeda secara statistik disebabkan karena senyawa flavonoid pada ekstrak daun burahol. Kandungan senyawa flavonoid pada herbal berperan penting dalam melindungi dinding mukosa usus halus (Setiawan dkk., 2018; Adibmoradi et al., 2006). Dinding mukosa yang terlindungi dengan baik dapat meningkatkan proses penyerapan nutrisi pada pakan ternak (Konan et al., 2012). Penyerapan nutrisi erat kaitannya dengan vili.

Menurut Fard et al., (2014) flavonoid dapat mempertinggi vili duodenum ayam. Peningkatan vili usus yang terjadi akibat efek dari senyawa flavonoid menyebabkan permukaan bidang absorpsi menjadi lebih luas sehingga penyerapan nutrien lebih optimal. Penyerapan nutrien yang optimal akan meningkatkan kecernaan nutrien termasuk didalamnya kecernaan protein. Kecernaan protein yang meningkat dapat mempengaruhi bobot usus halus. Berkaitan dengan fungsi protein menurut pendapat Ketaren (2010) yaitu protein berperan dalam pembentukan sel, mengganti sel yang mati dan membentuk jaringan tubuh. Sel jaringan tubuh yang dibentuk termasuk didalamnya yaitu sel epitel usus halus. Semakin banyak sel epitel usus halus maka permukaannya semakin luas dan jumlah vili akan semakin banyak sehingga bobot usus halus akan semakin berat.

\section{SIMPULAN}

Pemberian ekstrak daun burahol dalam ransum sebanyak $0,15 \%-0,45 \%$ tidak berpengaruh nyata $(\mathrm{P}>0,05)$ terhadap bobot organ jantung, hati, proventrikulus, ventrikulus dan usus halus ayam broiler.

\section{UCAPAN TERIMA KASIH}

Ucapan terima kasih disampaikan kepada seluruh pihak yang telah membantu penelitian ini, hingga penulisan artikel ini telah dilaksanakan dengan kontribusi yang sama dengan seluruh tim yang terlibat seperti yang tercantum sebagai penulis dalam artikel ini.

\section{DAFTAR PUSTAKA}

Adibmoradi, M., B. Navidshad, J. Seifdavati and J. M. Royan. 2006. Effect of dietary garlic meal on histological structure of small intestine in broiler chickens. J. of Poult. Sci. 43:378-383.

Adriani, L., A. Mushawwir, B.R. Anastasia and B. Rahayu. 2018. Effect of combination chitosan and turmeric powder (curcuma domestica val.) For improving blood lipid profile in broilers. Scientific Papers. Series D. Animal Science. LXI:225-229.

Amrullah. 2004. Nutrisi Ayam Broiler. Cetakan III. Bogor, Indonesia: Lembaga Satu Gunung Budi.

Anggorodi. 1994. Ilmu Makanan Ternak Umum. Jakarta, Indonesia: Penerbit Gramedia.

Aqsa, A. D., K. Kiramang, K., dan Hidayat. 2016. Profil organ dalam ayam pedaging (broiler) yang diberi tepung daun sirih (piper betlelinn) sebagai imbuhan pakan. J. Ilmu dan Industri Peternakan. 3:148-159.

Auza, A. F. 2010. Efektifitas Pemberian Serbuk Kunyit, Bawang Putih dan Mineral Zink Terhadap Kadar Kolestrol Darah dan Bobot Organ Dalam pada Broiler. Tesis. Universitas Hasanuddin. Indonesia. 
Awad, W. A., K. Ghareeb, Nitch, S. A. Raheem and J. Bohm. 2009. Effect of dietary inclusion of probiotic and synbiotic on growth performance, organ weight, and intestinal histomorphology of broiler chickens. Poult. Sci. 88:49-55.

Aziz, S. A and B. C. Ramadhan. 2013. Media and organic fertigation for growth and phyochemical properties of stelechocarpus burahol in nursery. International Seminar Proceddings Forest and Medical Plants for Better Humann Welfare. 200-204.

Bahri, S.,E. Masbulan dan A. Kusumanginsih. 2005. proses praproduksi sebagai faktor penting dalam menghasilkan produk ternak yang aman untuk manusia. Jurnal Litbang Pertanian. 24:123-127.

Cahyono, E. D., U. Atmomarsono dan E. Suprijatna. 2012. Pengaruh penggunaan tepung jahe (Zingeber offinale) dalam ransum terhadap saluran pencernaan dan hati pada ayam kampung umur 12 minggu. Anim. Agricultural J. 1:65-74.

Cushnie, T. P. T and A. J. Lamb. 2005. Atimickrobial activity of flavonoids. Int. J. off Antimicrobial Agents. 26: 343-356.

Dasagupta, P., P. Chakraborty and N. N. Bala. 2013. Averrhoa Carambola : an update review. International Journal of Pharma Research \& Review. 2:54-63.

DEPKES (Departemen Kesehatan Republik Indonesia). 2000. Parameter Standar Ekstrak Tumbuhan Obat. Edisi 1. Direktorat Jendral Pengawasan Obat dan Makanan. Direktorat Pengawasan Obat Tradisonal. Jakarta. Indonesia.

Fard, S. H., M. Toghyani and S. A. Tabeidian. 2014. Effect of oyster mushroom wastes on performance, immune responses and intestinal morphology of broiler chickens. The J. of Int. Recycl Org. Waste Agriculture. 3:141-146.

Frandson, R. D. 1992. Anatomi dan Fisologi Ternak. Edisi ke-4. Yogyakarta,
Indonesia: Gadjah Mada University Press.

Gasperz, V. 1991. Metode Perancangan Percobaan untuk Ilmu- ilmu Pertanian, Ilmu-ilmu Teknik, Biologi. Bandung, Indonesia : Armico.

Heyne K. 1987. Tumbuhan Berguna Indonesia. (Terjemahan) Jilid III. Jakarta, Indonesia: Badan Penelitian dan Pengembangan Kehutanan Jakarta.

Hidaka, M., M. Okumura, T. Ogikubo, H. Kai, T. Iwakiri, K Yamasaki, N Setoguchi, K. N. Fujita, N. Matsunaga and K. Kazuhiko. 2006. Transient inhibition of CYP3A in rats by star fruit juice. The American Society for Pharmacology and Experimental Therapeutics. 34:343-345.

Hidayat, A. L. K Darusman and I. Batubara. 2011. Fractination of the Active Compound From Kepel (Stelechocarpus burahol) Leaf Extract as Antibacterial. The $2^{\text {nd }}$ International Symposium on Temulawak. Pusat Studi Biofarmaka LPPM IPB. 112-113. Iyayi, E. A., O. Ogunsulo and R. Ijaya. 2005. Effect of three sources of fibre and period of feeding on the performance, carcase measures, organs relative weight and mmeat qulaity in broilers. Int. J. of Poult. Sci. 4:695-700.

Jumiati, S., Nuraini dan A. Rahim. 2017. Bobot potong, karkas, giblet dan lemak abdominal ayam broiler yang diberi temulawak (Curcumaxanthorrhiza, Roxb) dalam kakan. UHO. JITO. 4:5658.

Ketaren, P. P. 2010. Kebutuhan gizi ternak di Indonesia. Wartazoa. 4:172-180.

Konan, N. A., N. Lincopan, I. E. C. Diaz, J. F. Jacysyn, M. M. T. Tiba, J. G. P.A. Mendes, E. M. Bacchi and B. Spira. 2012. Cytotoxity of cashew Flavonoids towards malignant cell lines. Exp. Toxicol Pathol. 64:435-440.

Kusmiyati, E., P. Hastoetti dan Gusmailina. 2005. Potensi burahol sebagai komoditi hasil hutan bukan kayu yang terancam punah. Info Hasil Hutan. 11: 9-16. 
Lesson, S. and J. D. Summer. 2005. Poultry Feeds and Nutriton. Westport-CT, United States of America: The AVI Publishing Co. Inc.

Mushawwir, A. Y.K. Yong, L. Adriani, E. Hernawan, K.A. Kamil. 2010. The fluctuation effect of atmospheric ammonia $\left(\mathrm{NH}_{3}\right)$ exposure and microclimate on hereford bulls hematochemical. J. of the Indon. Tropical Anim. Agric. 35:232-238.

Mushawwir, A., L. Adriani and K.A. Kamil. 2011. Prediction models for olfactory metabolic and sows\% RNAreticulocyt (RNArt) by measurement of atmospheric ammonia exposure and microclimate level. J. of the Indon. Tropical Anim. Agric. 36:14-20.

Mushawwir, A. dan D. Latipudin. 2012. Respon fisiologi thermoregulasi ayam ras petelur fase grower dan layer. Proseding seminar zootechniques for Indogeneous resources development, ISAA Fakultas Petenakan Universitas Diponegoro. Proceeding of National Seminar on Zootechniques. 1:23-27

Mushawwir, A, U.H. Tanuwiria, K. A. Kamila, L. Adriani, R. Wiradimadja, and R. Suwarno, N. 2018. Evaluation of haemotological responses and blood biochemical parameters of heatstressed broilers with dietary supplementation of javanse ginger powder (Curcuma xanthorrhiza) and garlic extract (Allium sativum). Int. J. of Poult. Sci. 17:452-458.

Mushawwir, A., N. Suwarno dan A.A. Yulianti. 2019. Profil malondialdehyde (MDA) dan Kreatinin itik fase layer yang diberi minyak atsiri garlic dalam kondisi cekaman panas. J. Ilmu dan Industri Peternakan 5:1-11.

Mutia, R., R. K. Rusli., K. G. Wiryawan dan T. Toharmat. 2017. Pengaruh penambahan tepung kulit manggis dan vitamin $\mathrm{E}$ dalam pakan terhadap organ pencernaan, aksesori, reproduksi dan karkas ayam petelur. Buletin Peternakan. 41:257-264.
Ouyang, K., M. Xu, Y. Jiang and W. Wang. 2016. Effect of alfafa flavonoids on broiler performance, meat quality and gene expression. Canadian J. of Anim. Sci. 96:332-341.

Purwatingsih, I. Purwantini and D. Santoso. 2011. Identification of standard parameters of kepel leaves [stelechocarpus burahol (b.i) hook. f. \& th] and the extract as raw material for anty-hyperuricemic medicaments. Asian J. of Pharmaceutical and Clinical Res. 4:149-153.

Putnam, P. A. 1991. Hand book of Animal Science. San Diego, California: Academic Press.

Ramadhina, I.A., L. Adriani and E. Sujana. 2019. Pengaruh Pemberian ekstrak daun kepel (stelechocarpus burahol) terhadap kadar kolesterol darah dan telur puyuh (Coturnix-coturnix japonica). J. Nutrisi Ternak Tropis dan Ilmu Pakan. 1:34-40.

Regar, N, M., Kowel S. H. Y, B. Betty dan E. A. S. Moningkey. 2018. Pemberian kombinasi kunyit, bawang putih dengan mineral zink terhadap bobot organ dalam ayam pedaging yang diinfeksi E.coli. Prosiding Seminar Nasional Unggas Lokal: Pengembangan Unggas Lokal di Indonesia. 2:168172.

Rohmah, N., E. Tugiyanti dan Roesdiyanto. 2016. Pengaruh tepung daun sirsak (Announa muricata L) dalam ransum terhadap bobot usus, pankreas dan gizzard itik tegal jantan. J. Agripet. 16:140-146.

Setiawan, H., N. U. Listiatie dan M. Zulfikar. 2018. Serbuk daun jambu biji memperbaiki performans pertumbuhan dan morfologi duodenum ayam jawa super. J. Veteriner. 19:554-567.

Sunarni, T, S. Pramono dan R. Asmah. 2007. Flavonoid antioksidan penagkap radikal dari daun kepel (Stelechocarpus burahol). Majalah Kefarmasian Indonesia. 18:111-116.

Swarayana, I. M. I., I. W. Sudira dan I. K. Berata. 2012. Perubahan histopatologi 
Mencit (Mus musculus) yang Diberikan Ekstrak Daun Ashitaba (Angelica keiskei). Buletin Veteriner Udayana. 4:119-125.

Syamsuhaidi. 1997. Penggunaan Dukweed (family Lamanceae) sebagai Pakan Serat Sumber Protein dalam Ransum Ayam Pedaging. Disertasi. Insitut Pertanian Bogor. Indonesia.

Ukim, C. I., G. Ojewola, C. O. Obun and E. N. Delekwute. 2012. Performance and carcass and organ weights of broiler chicks feed graded levels of acha grains (Digitaria exilis). J. of Agriculture and Veterinary Sci. 1:28-33.

Ververidis, F., E. Trantas, C. Douglas, G. Vollmer, G. Kretzschmar and N. Panopoulos. 2007. Biotechnology of flavonoids and other phenylpropanoidderived natural products. part I: chemical diversity, impacts on plant biology and human health. Biotechnol J. 2:1214-1234.

Voight, R. 1995. Buku Pelajaran Teknologi Farmasi. Edisi Kelima. Yogyakarta, Indonesia: Gadjah Mada University Press.

Wu, Y., F. Wang and Q. Zheng. 2006, Hepatoprotective effect of total flavonoids from laggera alata againts carbon tetrachloride-induced injury in primary cultured neonatal rat hepatocytes and in rats with hepatic damage. J. of Biomedical Sci. 13:569578. 